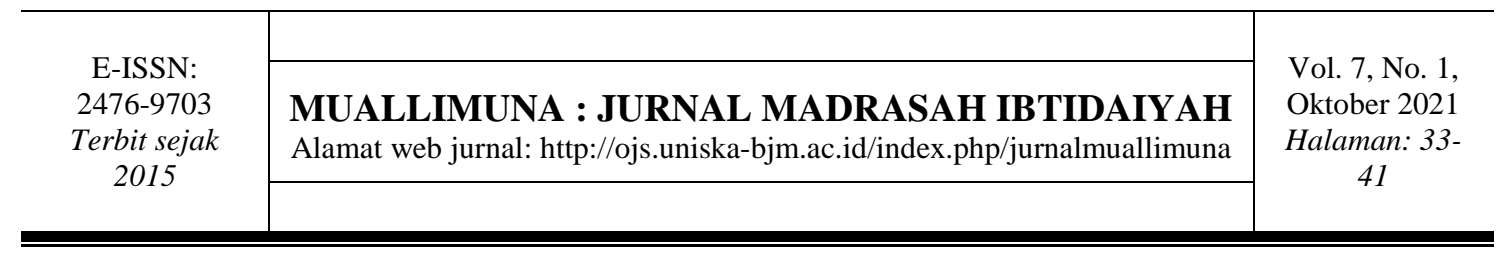

\title{
FLIPPED CLASSROOM: INNOVATIVE LEARNING TO INCREASE THE LEARNING MOTIVATION OF ELEMENTARY SCHOOL STUDENTS IN THE DIGITAL AGE
}

\author{
Jamilah $^{1}$, Tri Sukitman ${ }^{2}$, Mulyadi $^{3}$ \\ ${ }^{12}$ Elementary School Teacher Education Departement STKIP PGRI Sumenep \\ ${ }^{3}$ Mathematics Education Departement STKIP PGRI Sumenep \\ 1'jamilah@ stkippgrisumenep.ac.id, ${ }^{2} \underline{\text { trisukitman@ @ stkippgrisumenep.ac.id }}$

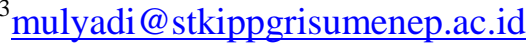

\begin{abstract}
Today's digital age has an important impact on education. One of the learning models to increase the motivation of learners in learning in the digital era is flipped learning with reverse learning models. This research is a type of literature research. This research data source uses a variety of literature from various journals. Data analysis in this study uses content analysis. The results of this study show that the application of flipped classroom in the digital era has been able to increase students' learning motivation both at school and at home. Because students have studied the learning material before entering the class which means that the teacher is no longer dominant in controlling the class so that the interaction between the teacher and students becomes better and is very enjoyable in learning. Therefore when designed effectively, the flipped classroom method can increase the students' motivation towards the course. Also, suggestions for practitioners were discussed in this study
\end{abstract}

\section{Keywords: learning, flipped learning, digital era}

\section{FLIPPED CLASSROOM: PEMBELAJARAN INOVATIF UNTUK MENINGKATKAN MOTIVASI BELAJAR SISWA SEKOLAH DASAR DI ERA DIGITAL}

\begin{abstract}
Abstrak: Era digital saat ini memiliki dampak penting terhadap pendidikan. Salah satu model pembelajar untuk meningkatkan motivasi peserta didik dalam pembelajaran di era digital adalah pembelajaran flipped learning dengan model pembelajaran terbalik. Riset ini merupakan jenis penelitian pustaka. Sumber data penelitian ini menggunakan berbagai literatur dari berbagai jurnal. Analisis data dalam penelitian ini menggunakan analisis isi. Hasil penelitian ini menunjukkan dengan penerapan flipped classroom di era digital telah mampu meningkatkan motivasi belajar siswa baik di sekolah maupun di rumah. Hal ini disebabkan karena siswa telah mempelajari materi pembelajaran sebelum masuk kelas yang memiliki makna guru tidak lagi dominan untuk menguasai kelas sehingga interaksi guru dan siswa menjadi lebih baik dan sangat menyenangkan dalam pembelajaran. Oleh karena itu ketika dirancang secara efektif, metode kelas terbalik dapat meningkatkan motivasi siswa terhadap kursus. Juga, saran untuk praktisi dibahas dalam penelitian ini.
\end{abstract}

Kata Kunci: pembelajaran, flipped learning, digital era 


\section{INTRODUCTION}

In this era of globalization, the developments of technology have a direct impact on improving the quality of education today as well as teaching and learning activities. Human resources in this case teachers, who are intelligent, excellent can compete competitively to achieve a higher level of life to produce good education (Hasbullah, 2013). According to Wolff, L. C. \& Chan, (2016) technology has not only changed the modern way of life but also teaching and learning habits. In other words, technology is not only changing the modern way of life but also the habits of learning and teaching.

The Flipped classroom is a learning strategy that employs IT in learning. This learning strategy involves student's active and independent learning through video as a medium before entering class. Class is used only to actively interact in solving difficult (Bergmann J, Rotellar C, 2016). Also, the flipped classroom is also proven to be effective for a large class, can generate positive perceptions of students towards the learning process, and can improve learning outcomes (Bergmann, J. \& Sams, 2012).

The implementation of flipped classes has a very different structure, students must prepare for the next lesson, and then the teacher provides an opportunity for students to actively participate in classroom learning (Keengwe, 2014).

The Flipped classroom is a learning model that rearranges and reschedules the time used both outside and inside the classroom, by increasing students' independent learning time compared to learning from teachers or educators (Yulhendri, 2016).

\section{FLIPPED CLASSROOM}

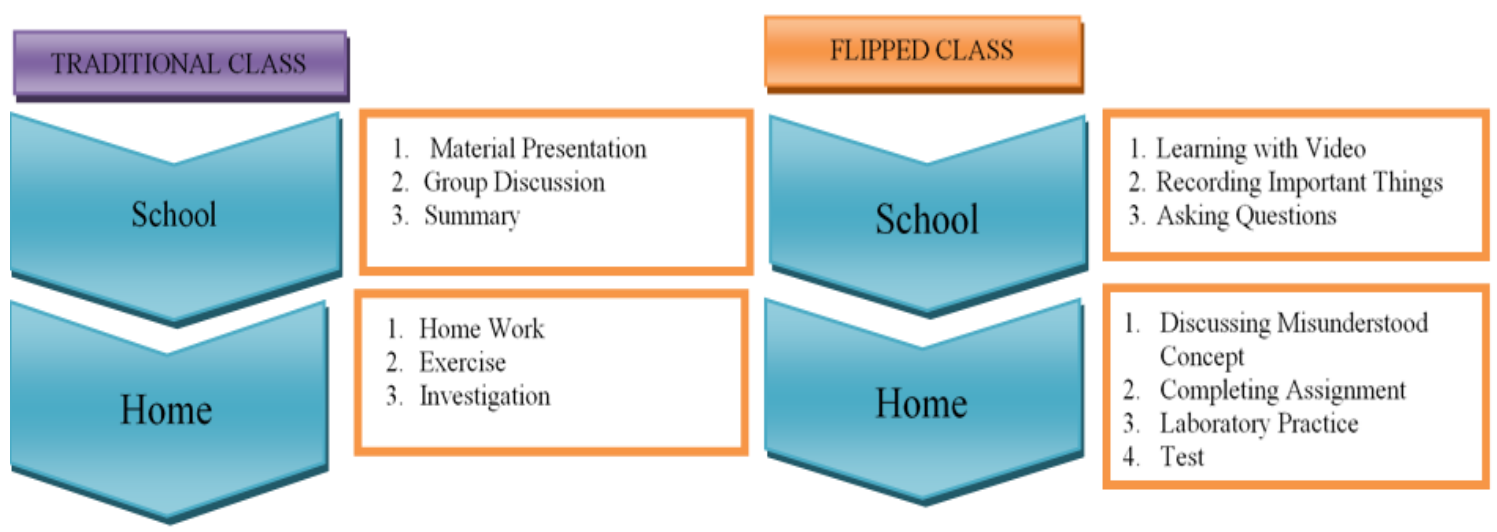

Figure 1: Flipped Classroom Learning Model

As Bergman said in the book Carbough \& Doubet entitled The Differentiated, a teacher who uses the flipped classroom has full control over their students and holds students responsible for their own learning. In this case, students are given space to study. Motivation provides a boost to actions aimed in the desired direction both physically and mentally, so activity becomes a very important part.The series of processes above is a flipped classroom link with Bloom's Taxonomy described shown in Figure 2. 


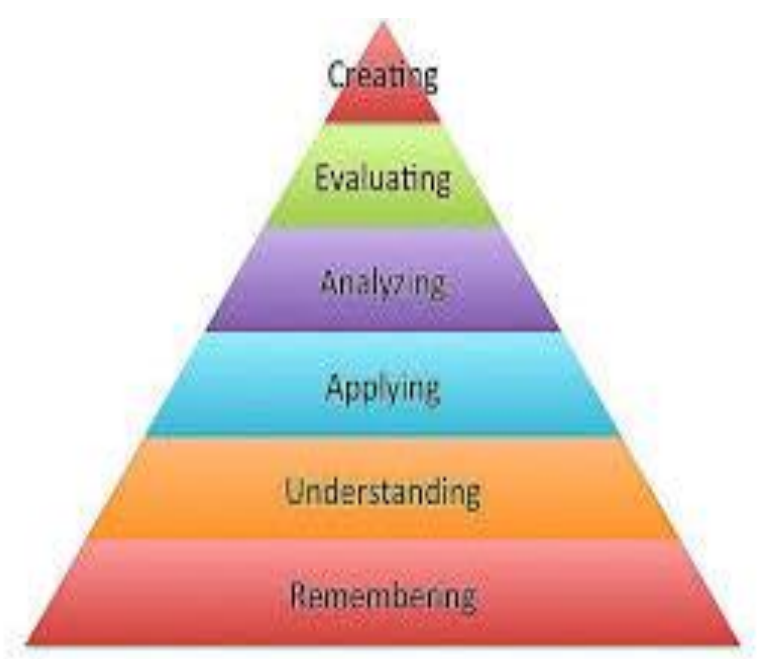

Figure 2: Taxonomy Bloom's model

Independently, while the teacher functions as control of the activities carried out by students (Carbaugh \& Doubet, 2014). Bergmann, J. \& Sams, (2012) created an inverted classroom shape to describe a learning model that combines hands-on learning with a constructivist learning experience. This model provides an opportunity to bring more natural technology into the classroom and explore more creative ways to engage students in learning (Smaldino et al., 2016).

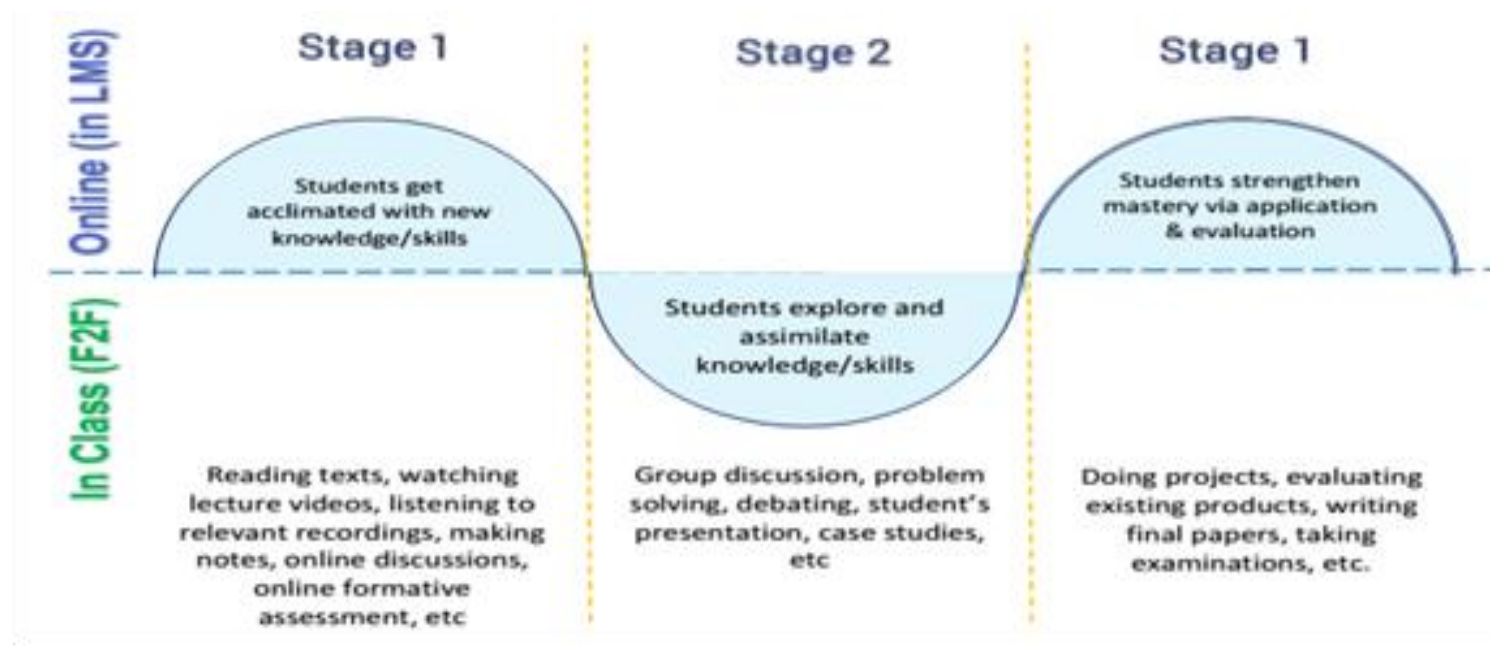

Figure 3: Stages and Modes of Learning in Flipped Classroom

In this reverse classroom learning model, teachers can record their own videos and deliver learning materials using various technological applications (Zainuddin \& Perera, 2018). Another study mentions that learners are successful in improving their learning achievement with this flipped classroom learning model. One reason is because they can prepare learning materials before coming to class (Awidi \& Paynter, 2019)..

Based on a report by the New Media Consortium (NMC) which annually releases the latest technology in the world of education. From the report it is said that flipped classroom learning includes the latest innovation media section and is highly recommended to be applied to higher education. The goal is to build individual learners' learning skills and critical thinking. Shyr and Chen (2018) in their research also 
mentioned that this flipped classroom learning model has been applied around the world, both in schools and in colleges, for various fields of study. This article contains a discussion related to efforts to build student motivation through flipped classroom

\section{Research Design}

\section{METHOD}

This study used library research. Library research involves a step-by-step process used to gather information to write a paper, make a presentation, or complete a project. Furthermore, library research is research that is used to collect information from various data such as documents, books, and journal (Sugiyono, 2013).

\section{Data collection}

In this study, data collection was obtained from several articles in online journals. Researchers search for articles using keywords with reverse learning, learning models, and with innovative learning (Arikunto, 2010).

\section{Data Analysis}

Data analysis of this research uses content analysis which contains an in-depth discussion of the content of information both in writing and in print. The data in this study are research results such as scientific books, scientific journals, research reports, and other relevant sources.

\section{RESULT AND DISCUSSION Result}

The flipped classroom is a learning strategy that uses a type of blended learning approach by reversing the traditional learning environment and providing learning content outside the classroom (mostly online) carried out during a face-to-face class session.

Discussion of assignments (material traditionally considered homework) or the educator can ask the class to discuss the question items related to the exam. Some educators also watch streaming video lectures or collaborate in online discussions as classroom activities with careful supervision by the facilitator (Zainuddin dan Keumala: 2018).

This is in line with the theory presented by Johnson, (2013) that states that classrooms are a strategy that educators can provide by minimizing the amount of direct instruction in their teaching practices while maximizing interaction with each other. The flipped classroom approach does not change the pedagogic concept however, it only changes the role of students from passive listeners in class to actively participating in learning activities.

In implementing flipped classrooms in the following years, educators can use the previous material if there are no revisions in teaching. Also besides, there is student's anxiety in implementing the flipped classroom because they ha ve to watch videos and finish reading the reading materials provided before the class meeting. This should not be considered a disadvantage in a flipped classroom, because this situation is beneficial to improve learning.

Dean DL \& Ball N (2013) argues that students may experience difficulties in fulfilling the responsibilities and expectations of educators in the flipped classroom model. In this case, a gradual transition is needed in the implementation of flipped classrooms, sharing responsibilities in a fun way, sharing tasks in a clearly way, and providing rewards that can facilitate the transition period. In some situations, students 
have challenges in implementing flipped classrooms because they do not have access to internet technology. Also, the flipped classrooms are reported to have been successful in building a good culture of interaction between learners, teachers, teaching materials, and technology media.

The last challenge also faced is that the students' attitude who have not been able to accept flipped classroom because they feel comfortable with traditional classes which are passive learning. Flipped classroom learning cannot be used in every learning environment. In flipped classrooms, students must meet regularly in face-to-face settings, students must have ready access to whatever technology is used to communicate outside of the classroom, and in-class instruction designed must include learner-centered assignments completed as part of the learning community.

Through the flipped Classroom model, students are encouraged to learn independently using links to subject matter that the teacher has built on the web in the form of online videos before coming to class. In this way, students will have more time in class to discuss and solve problems they find while studying on their own. With the Flipped Classroom model, students are encouraged to learn independently using links to subject matter that the teacher has built on the web in the form of online videos before coming to class. In this way students will have more time in class to discuss and solve problems they find while studying on their own.

Students are easier to understand the subject matter by using the Flipped Classroom learning model. In addition, students feel more interested in taking lessons so that students are more enthusiastic and feel happy when the lesson takes place. This can foster learning motivation for students which will have a positive impact on their learning outcomes.

\section{Discussion}

Student learning outcomes with flipped classroom learning proved to be higher than students' learning outcomes with expository learning strategies. On expository learning students just wait and receive what the teacher will give while in the classroom. Students are passive and only receive knowledge provided by teachers, the learning process is teacher center (teacher-centered). Teachers are required to prepare appropriate teaching materials in a classroom setting that supports students to enjoy learning. Furthermore, the process of flipping the class, where students actively learn the material first at home and present it when in class. Some literatur about video-based flipped classroom design has shown mixed results regarding students' learning motivation.

This is in accordance with of Zainuddin and Perera's (2019) research that an inverted classroom environment has a positive influence on students' intrinsic motivation. Research that conducted (Lanqin Zheng, et al., 2020) flip classroom was able to improve learning motivation. Further Research (Gawise, 2021) is effective in improving learning outcomes

This process becomes complicated when the teacher does not have a reference for the proper evaluation of learning related to the tasks that students must complete at home because students do not understand what is being done. In this learning design, a system is developed that can be used by students online and there are even features that support students to interact well with each other. students as well as with teachers. Flipped classroom learning is designed to 1. Provide opportunities for students to get their first exposure before class 2. Give time for students to prepare for class 3. Provide a mechanism for assessing student understanding 4. Provide a clear connection between 
activities in the classroom and outside the classroom 5. Provide clear and wellstructured guidelines 6. Provide enough time for students to carry out assignments 7. Provide facilitation to build a learning community.

In the learning process, the teacher can create various learning models in the classroom in reverse according to the specified material. The application of learning models does not only depend on technology, but also on how to handle various learning models, especially how educators can develop the abilities of participants and students (Nederveld \& Berge, 2015). Researchers have conducted research on motivation in various reverse classes and it has had a positive impact.

In the AR-based reverse learning system, fifth grade students' learning achievement, learning motivation, critical thinking tendencies, and group self-efficacy increased significantly (Chang \& Hwang, 2018). Previous research has shown that students' motivation and development of learning strategies have a deep relationship to their academic performance and learning skills.

Released the results of his research and reported that the learning outcomes of students with the flipped model were significantly better than learning outcomes in conventional classes. Furthermore, formative assessment through quizzes is also one of the reasons why students can improve their learning achievement in this flipped class. Also besides have more time to provide learning feedback to students. Kim et al., (2014) states that through formative assessment in flipped classes, teachers can evaluate the progress of students in their learning and students will also better understand what they need to improve from the deficiencies they still have.

One of the newest digital-based learning models currently using video learning as a learning medium outside of the classroom is flipped classroom. This learning model guides students to learn independently through learning videos before coming to class. Classroom activities are more focused on discussion activities, no longer focused on the teacher's long lecture (Alamri, 2019).

Shih and Tsai (2017) also reported the results of the neutral agreement showed a reverse classroom approach can increase students' learning motivation. The use of one or more of these programs can be an alternative for teachers to succeed in implementing flipped classrooms. Clear, meaningful, and engaging content will help students understand the subject matter before they get into the classroom.

The study conducted has both similarities by comparing the two classes, but the difference is the researcher uses a flipped classroom with parental assistance and a flipped classroom without parental assistance. In line with (M. Eko Arif Saputra, 2018) as a researcher who research the understanding of mathematical concepts, this study focuses on the material of proper fraction and mixed fractions

Flipped classroom is a learning activity or the art of teaching (pedagogy) in which students learn the learning material through video at home or before class; while the activities in class are mostly group discussions and questions and answers. In this flipped classroom learning model, teachers can record their own videos and deliver learning materials using various technology applications (video recorder software) (Zainuddin \& Perera, 2018). Also besides, videos can be edited using various software. There are various free video applications in Windows application that can be used by teachers in preparing instructional videos, such as Movie Moments, Power Director, or Movie Maker. One of the big obstacles in the implementation of this learning model is the lack of motivation for learners to study the material independently outside the classroom. 
The application of flipped classroom is not without challenges. In a critical review that synthesized 15 peer reviewed articles on the challenges of implementing flipped classrooms at the elementary and secondary education levels conducted by Lo and Hew (2017), there were a number of challenges in terms of students, teachers, and operational aspects. In addition to identifying a number of challenges, the study also provides a number of alternative solutions to address these problems. Through the use of flipped classroom learning models, it is expected that limited time in the classroom can be utilized as well as possible to learn things that require high-level thinking skills or High Order Thinking Skills (HOTS) or things that students do not fully understand.

In terms of teaching video material, Jamilah (2020) emphasizes that if the content of the learning video is not interesting and fun, students tend to get bored easily to watch it outside the classroom. Therefore, teachers are highly required to really prepare interesting learning videos (Smaldino et al., 2016). In the face of the digital era and the 4.0 industrial revolution, teachers in higher education are highly required to be able to adapt to technological advances and innovative pedagogy in learning.

It should be noted that innovative pedagogy and technology in learning are not only limited to videos, Mp3, PowerPoint or projectors, computers, and the internet but also the latest technological trends in education such as the concept of blended learning, mobile learning, augmented reality, gamification, based learning. games, learning analytics, and the Massive Open Online Course (MOOC). (Gasong, 2018) revealed that success in teaching and learning process is determined by several factors, both from within and from outside the community. This research is more in-depth about the collaborative role of education in applying flipped classrooms to find out the influence of student motivation and learning outcomes.

With this fact flipped classroom learning in the future can be an alternative to learning in order to achieve learning goals as well as efforts to improve the quality of education. Even this strategy will continue to be optimized through improving the quality of learning videos, for example with interactive videos that can increase students' learning motivation. It is expected that with interactive videos, the percentage of students who do not do self-learning is reduced, not even at all. This research activity is in line with (Lanqin Zheng, et al., 2020) showed bahwa flipped classroom is able to give an impact on student's learning motivation.

In short, the literature on motivation in flipped classrooms shows that educators' emphasis is on how different inverted classroom instruction affects students' learning motivation. Since there is no one model for flipping classrooms, instructors may have different implementations, which can cause different effects on student course performance, completion of assigned course materials, time spent studying, and a sense of classroom community. Thus, students' motivation can grow through what they like and something interesting according to their age level. One of them is the medium used in the learning process.

In addition, learning can be done online which is integrated with the assessment system. This will be more binding to the student, because currently the student will feel responsible if learning is associated with the assessment process. Assessment of the process can be done by the teacher through the online system. This will ease the burden on teachers when it comes to manually assessing the learning process in the classroom. With technology, all teachers' jobs will be lighter including the assessment process. 


\section{CONCLUSION}

Flipped classroom is a learning model combined with technology so that the learning process is more active and efficient. So that students are actively involved in problem solving. This learning model is also expected by students to have the motivation and confidence to learn in class by participating in discussion activities, asking questions and providing solutions in completing various. For this reason, teachers must have the right learning innovations to increase the independence and confidence of students to develop various knowledge in the digital era as it is today. In additions, teachers, parents and students need to follow up by analyzing students' requirements according to their needs. Thereafter, further research is needed related to the impact of online learning to learning outcomes in other aspects.

\section{BIBLIOGRAPHY}

Alamri, M. M. (2019). Students' academic achievement performance and satisfaction in a flipped classroom in Saudi Arabia. International Journal of Technology Enhanced Learning, 11, 103-119.

Arikunto. (2010). Prosedur Penelitian Suatu Pendekatan Praktik. Rineka Cipta.

Awidi, I. T., \& Paynter, M. 2019. The impact of a flipped classroom approach on student learning experience. Computers \& Education, Vol. 128, hal. 269-283

Bergmann J, Rotellar C, C. J. (2016). Research, perspective, and recommendation on implementing the flipped classroom. American Journal of Pharmaceutical Education.

Bergmann, J. \& Sams, A. (2012). Flip Your Classroom: Reach Every Student in Every Class Every Day. ISTE.

Carbaugh, E. M., \& Doubet, K. J. (2014). The Differentiated Flipped Classroom. Corwin Hmelo-silver.

Chang, S. C., \& Hwang, G. J. (2018). Impacts of an augmented reality-based flipped learning guiding approach on students' scientific project performance and perceptions. Computers \& Education, 125, 226-239. https://doi.org/10.1016/j.compedu.2018.06.007

Dean DL, D. R., \& Ball N. (2013). Flipping the classroom and instructional technology integration in a college-level information systems spreadsheet course. Educ Technol Res Dev, 61(4), 563-580. https://doi.org/https://doi.org/10.1007/s11423013-9305-6

Enfield, J. (2013). Looking at the impact of the flipped classroom model of instruction on undergraduate multimedia students at CSUN. TechTrends, 5, 14-27.

Eppard J \& Rochdi A. A Framework for Flipped Learning. 13th International Conference Mobile Learning 2017

Hasbullah. (2013). Dasar-dasar Ilmu Pendidikan. Rajawali Pres.

Gawise. (2021). Efektifitas Pembelajaran Model Flipped Classroom masa Pandemi Covid-19 terhadap Hasil Belajar di Sekolah Dasar. Edukatif: Jurnal Ilmu Pendidikan, 3(1), 246-254.

Jamilah. (2020a). Guru Profesional di Era New Normal: Review Peluang dan Tantangan dalam Pembelajaran Daring. Premiere Educandum: Jurnal Pendidikan Dasar Dan Pembelajaran, $10(2)$,

238-247. https://doi.org/https://doi.org/10.25273/pe.v10i2.7494

Johnson, G. B. (2013). Student Perceptions Of The Flipped Classroom. The University Of British Columbia. 
Johnson, L., Becker, S., Estrada, V., \& Freeman, A. 2015. NMC Horizon Report: 2015 Higher Education Edition (Rep.).

Kim, M. K., Kim, S. M., Khera, O., \& Getman, J. (2014). The experience of three flipped classrooms in an urban university: An exploration of design principles. The Internet and Higher Education, 22, 37-50.

Lanqin Zheng, Kaushal Kumar Bhagat, Y. Z. and X. Z. (2020). The Effectiveness of the Flipped Classroom on Students' Learning Achievement and Learning Motivation. Educational Technology \& Society, 23(1), 1-15.

Lee, J., \& Martin, L. (2017). Investigating Students' Perceptions of Motivating Factors of Online Class Discussions. International Review of Research in Open and Distance Learning, 18(5), 148-172. Https://Doi.Org/10.19173/Irrodl.V18i5.2883.

M. Eko Arif Saputra, M. M. (2018). Efektivitas Model Flipped Classroom Menggunakan Video Pembelajaran Matematika terhadap Pemahaman Konsep. Desimal: Jurnal Matematika, 1(2), 173-179

Nederveld, A., \& Berge, Z. L. (2015). Flipped learning in the workplace. Journal of Workplace Learning, 27(2), 162- 172. https://doi.org/10.1108/JWL-06-2014-0044

Purba, S. E. E., Kristiani, Sangka, K. B., \& Hussain, O. K. (2021). An Overview of its Impact on Economics Learning. International Journal of Pedagogy and Teacher Education, 5(1), 26-34. https://dx.doi.org/10.20961/ijpte.v5i1.49750.

Syakdiyah, H., Wibawa, B., \& Syahrial, Z. (2019). Flipped classroom learning inovation as an attempt to strengthen competence and competitiveness of students in the 4.0 industrial revolution era. Formatif: Jurnal Ilmiah Pendidikan MIPA, 9 (4): 267-280. http://dx.doi.org/10.30998/formatif.v9i4.2929

Shih, W. L., \& Tsai, C. Y. (2017). Students' perception of a flipped classroom approach to facilitating online project-based learning in marketing research courses. Australasian Journal of Educational Technology, 33(5), 32- 49. https://doi.org/10.14742/ajet.2884

Smaldino, S. E., Lowther, D. L., Mirns, C., \& Rusell, J. D. (2016). Instructional Technology and Media for Learning. Pearson.

Sugiyono. (2013). Metode Penelitian Pendidikan Pendekatan Kuantitatif, Kualitatif, dan $R \& D$. Alfabet.

Ts Tse, W. S., Choi, L. Y., \& Tang, W. S. (2019). Effects of video- based flipped class instruction on subject reading motivation. British Journal of Educational Technology, 50(1), 385-398. https://doi.org/10.1111/bjet.12569

Wolff, L. C. \& Chan, J. (2016). Flipped Classroom For Legal Education. Springer.

Yul, Amdhi Fadlul \&Ramadani, N. (2020). Gambaran Motivasi Belajar Simulasi Digital Menggunakan Smartphone. Jurnal Edik Informatika, 6(2).DOI: https://doi.org/10.22202/ei.2020.v6i2.4005

Yulhendri, T. K. (2016). Flipped Learning Berbasis Web Pada Pembelajaran di Universitas Negeri Padang. Jurnal Pendidikan Ekonomi Fakultas Ekonomi Universitas Negeri Padang.

Zainuddin, Z., \& Perera, C. J. (2018). Supporting students' self directed learning in the flipped classroom through the LMS TES BlendSpace. On the Horizon, 26, 281290. 